7. Reprod. Fert. (1973) 33, 69-75

\title{
CONTINUOUS MEASUREMENT BY RADIO-TELEMETRY OF VAGINAL pH DURING HUMAN COITUS
}

\author{
C. A. FOX, ${ }^{*}$ S. J. MELDRUM $\dagger$ AND B. W. WATSON $\dagger$ \\ * Williamson Laboratory, Academic Department of Obstetrics and Gynaecology, and \\ $\dagger$ Department of Medical Electronics, St Bartholomew's Hospital, London, E.C.1
}

(Received 29th February 1972)

Summary. The use of the $\mathrm{pH}$-pill has allowed continuous monitoring of vaginal $\mathrm{pH}$ during human coitus. In the case of a couple of normal fertility, there was an immediate buffering by seminal plasma so that the vaginal $\mathrm{pH}$ changed in $8 \mathrm{sec}$ from $\mathrm{pH} 4 \cdot 3$ to $\mathrm{pH} 7 \cdot 2$. In the case of a couple of low (male) fertility, the immediate effect of the arrival of semen in the vagina was a change from $\mathrm{pH} 3.5$ to $\mathrm{pH} 5 \cdot 5$. A similarly small change in $\mathrm{pH}$ occurred when the seminal volume of a fertile male subject had been depleted, by repeated ejaculation, to $1.5 \mathrm{ml}$. At this $\mathrm{pH}$ $(5 \cdot 5)$, spermatozoa are generally immobilized.

It has been possible to alter normal fertility, as judged by postcoital tests for sperm motility, by the introduction of a $\mathrm{pH} 3.6$ buffer solution into the vagina before coitus. In this latter experiment, the vaginal $\mathrm{pH}$ immediately after ejaculation was 5.0 and, after $2 \mathrm{hr}$, had reached $\mathrm{pH}$ $5 \cdot 4$.

These results in vivo suggest that the vagina is not the hostile environment hitherto imagined, since the normal ejaculate readily overcomes the vaginal acidity by its powerful buffering action. Low seminal volume, with or without a concomitantly low sperm count, and artificial changes in vaginal environment by buffer solutions may affect fertility.

\section{INTRODUCTION}

Numerous investigators have studied the effect of acidity upon the motility of human spermatozoa in vitro (Muschat, 1926; Randall \& Muschat, 1926; Baker, Ranson \& Tynen, 1937; Shedlovsky, Belcher \& Levenstein, 1942; Blackshaw \& Emmens, 1951; Masters, 1960; Diasio \& Glass, 1971), whilst similar experiments in the bull have been reported by Smith \& Asdell (1940), Easley, Mayer \& Bogart (1942), Anderson (1946) and Blackshaw \& Emmens (1951).

Tyler (1959) described experiments involving the removal of human cervical mucus at varying times post coitum for microscope studies of sperm motility and $\mathrm{pH}$. The first studies in vivo on the effect of vaginal acidity upon the motility of human spermatozoa were reported by Masters (1959, 1960) and Masters \& Johnson (1961) and were reviewed by Masters \& Johnson (1966). These pioneer 
studies demonstrated the importance of the vaginal environment in fertility, but involved the intermittent measurement of vaginal $\mathrm{pH}$ post coitum by the use of glass electrodes.

We now report the first continuous measurements made possible by the advent of radio-telemetry.

\section{MATERIALS AND METHODS}

The apparatus consisted of a $\mathrm{pH}$-sensitive telemetry capsule, a loop aerial, a radio receiver and a pen recorder. The telemetry capsule has been developed from the original specification of Watson \& Kay (1965) and consists of a glass $\mathrm{pH}$ electrode, a transmitter circuit and a mercury battery encapsulated in a 'Perspex' body. A silver chloride reference electrode is included in the replaceable battery cap, the complete unit measuring $25 \times 9 \mathrm{~mm}$ when assembled. Its use intravaginally is quite acceptable since it closely resembles an ordinary therapeutic pessary in size and can be inserted by the female into the posterior fornix of the vagina. Furthermore, the use of telemetry means an absence of wires, in contrast to conventional $\mathrm{pH}$ electrodes, so that the subjects could use the apparatus in the privacy of their own homes (see Fox, Wolff \& Baker, 1970).

The capsule transmits in the band 400 to $500 \mathrm{kHz}$ and responds linearly between $\mathrm{pH} 1$ and 12 . Before use, it is calibrated in buffer solutions at $37^{\circ} \mathrm{C}$. Should the vaginal temperature differ from this value during the course of an experiment, the error introduced is of the order of $0.1 \mathrm{pH}$ unit per degree C. Once activated, the life-time of the device is about 10 days and, over this period, the baseline stability is typically $0 \cdot 1 \mathrm{pH}$ unit per day. A Frequency Modulation receiver developed for use with these capsules is employed to receive the radio signals and process the information for presentation on a chart recorder. The transmitter and receiver (Plate 1) form part of a system previously developed for studies in gastroenterology (Watson \& Kay, 1965) and are now commercially available (Rigel Research Ltd, Richmond, Surrey).

The subjects for this investigation were (a) a couple of known fertility, the male having a sperm count of about $100 \times 10^{6} / \mathrm{ml}$ and a seminal volume of 5 to $6 \mathrm{ml} /$ ejaculate, after at least 4 days abstinence. They have four children, and the female partner had been taking the oral contraceptive 'Orlest 28' (containing $1 \mathrm{mg}$ norethisterone and $0.05 \mathrm{mg}$ ethinyloestradiol) for the previous 12 months and throughout the experiments; (b) a couple of low fertility, the male having a sperm count of $<4 \times 10^{6} / \mathrm{ml}$ and a seminal volume of $<2 \mathrm{ml}$ per ejaculate, after at least 4 days abstinence. They have one child by $\mathrm{AIH}$, and a further conception has since taken place by the same means. The female partner was not on any medication during the experiments.

The composition of the $\mathrm{pH} 3.6$ buffer used in some experiments was $70 \mathrm{ml}$ $0.1 \mathrm{~m}$-citric acid and $30 \mathrm{ml} 0.2 \mathrm{~m}$-disodium hydrogen phosphate, the vehicle being $5 \%$ methylcellulose.

Fertile couple

\section{RESULTS}

The immediate effect of the arrival of semen in the vagina was a change of 
PLATE 1
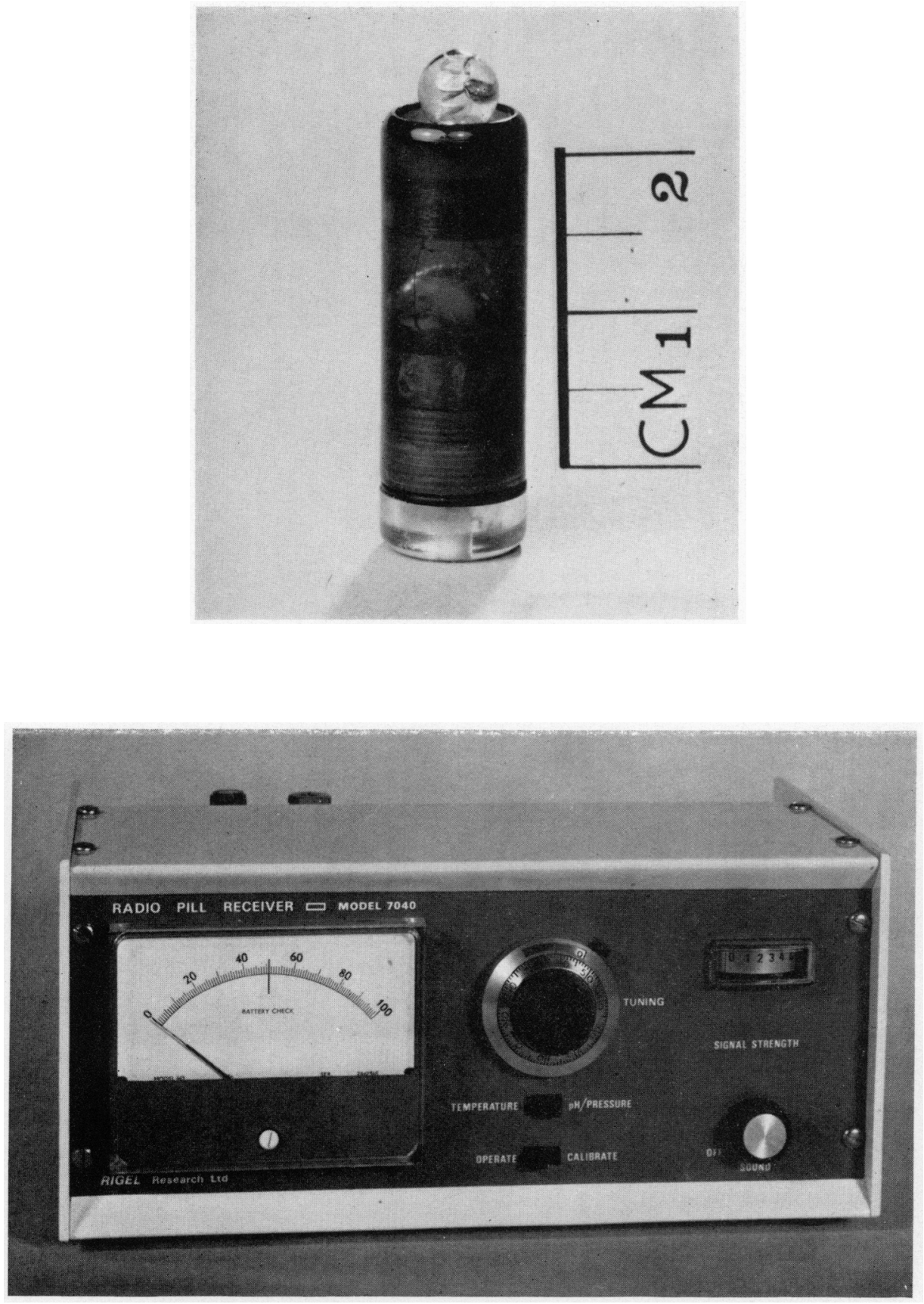

Photographs showing $\mathrm{pH}$-pill and radio-receiver.

(Facing p. 70) 
vaginal $\mathrm{pH}$ from $4 \cdot 3$ to $7 \cdot 2$ in $8 \mathrm{sec}$ (Text-fig. 1). Depletion of seminal volume (by four ejaculations within $48 \mathrm{hr}$ ) to $1.5 \mathrm{ml}$ resulted in a change of vaginal $\mathrm{pH}$, at intercourse, from 3.8 to 5.8 (Text-fig. 2). The effect of coitus and female

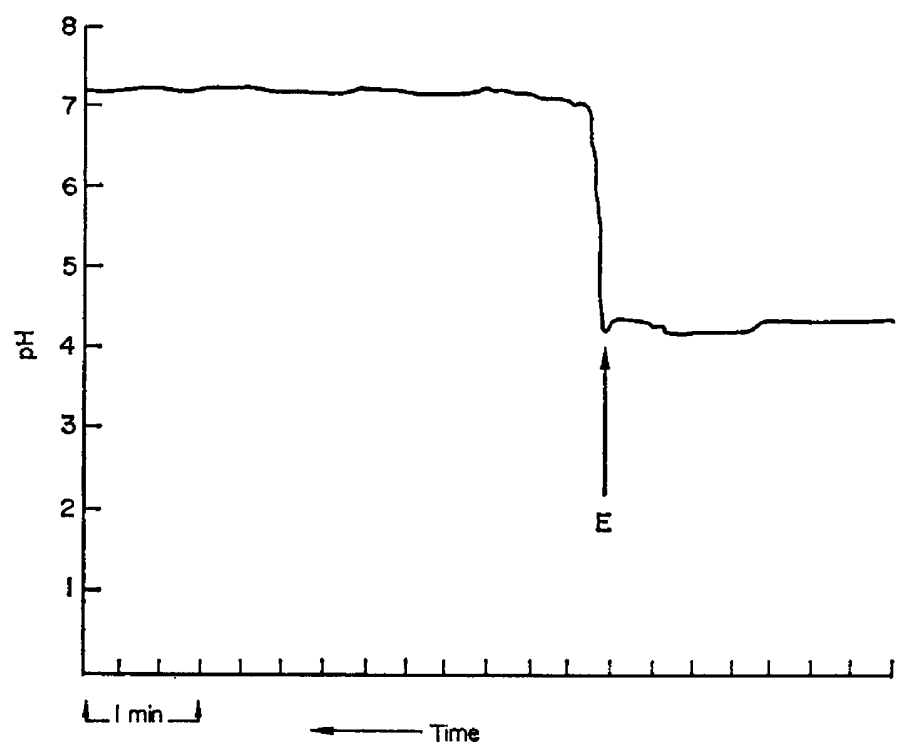

Text-Fig. 1. Effect of normal semen on vaginal $\mathrm{pH}$ during and after human coitus. $\mathbf{E}=$ ejaculation.

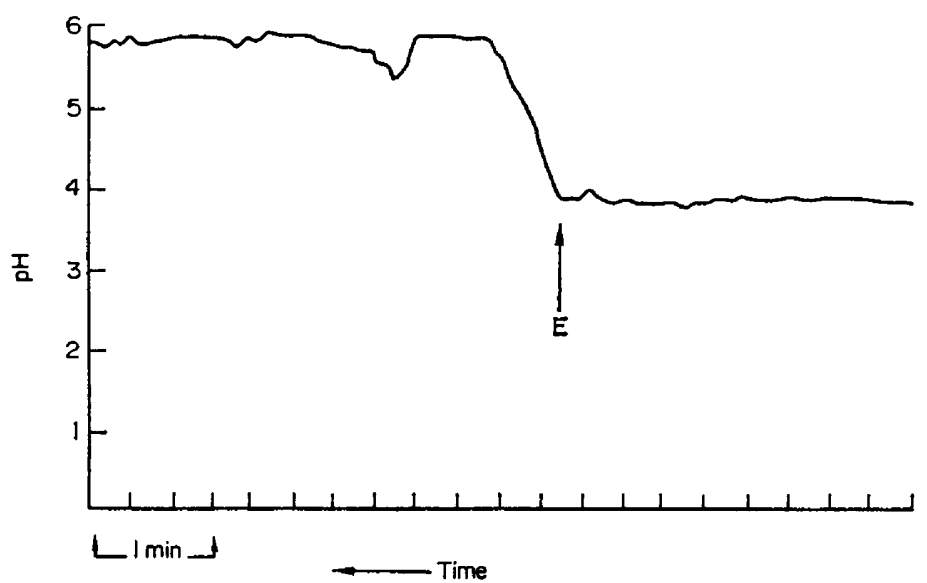

Texr-Fic. 2. Effect of low seminal volume (due to repeated ejaculation in a fertile subject) on vaginal $\mathrm{pH}$ during and after human coitus. Note smaller and slower change in vaginal $\mathbf{p H} . \mathbf{E}=$ ejaculation.

orgasm in the absence of semen (the male using a condom) was that no change in vaginal $\mathrm{pH}$ occurred (Text-fig. 3 ).

The use of a pH 3.6 buffer solution intravaginally during intercourse resulted in no change in vaginal $\mathrm{pH}$ during the first 2 min post coitum (Text-fig. 4) but after $2 \mathrm{hr}$, the vaginal $\mathrm{pH}$ was $5 \cdot 4$. In this experiment, three postcoital tests for 


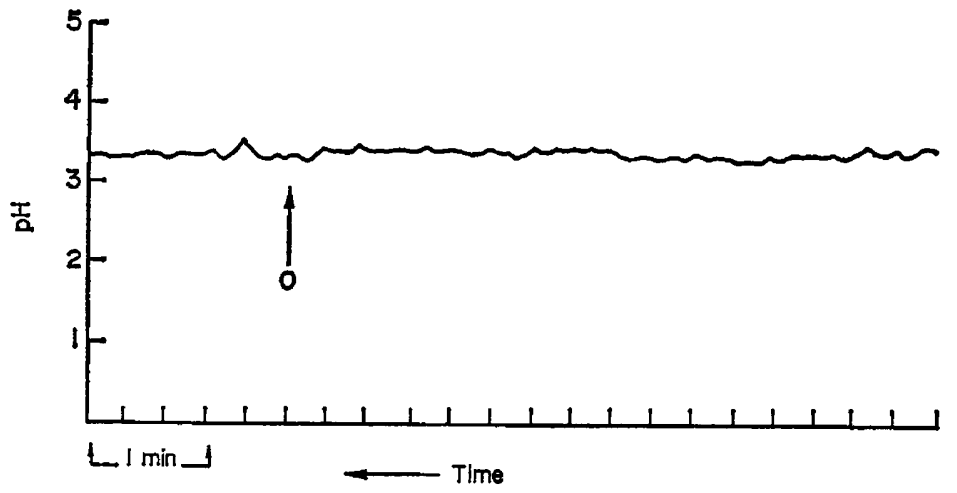

TEXT-Fig. 3. Effect of female orgasm on vaginal $\mathrm{pH}$ in the absence of semen. Note absence of change in vaginal $\mathrm{pH}$ despite sexual excitement and orgasm. $\mathrm{O}=$ orgasm.

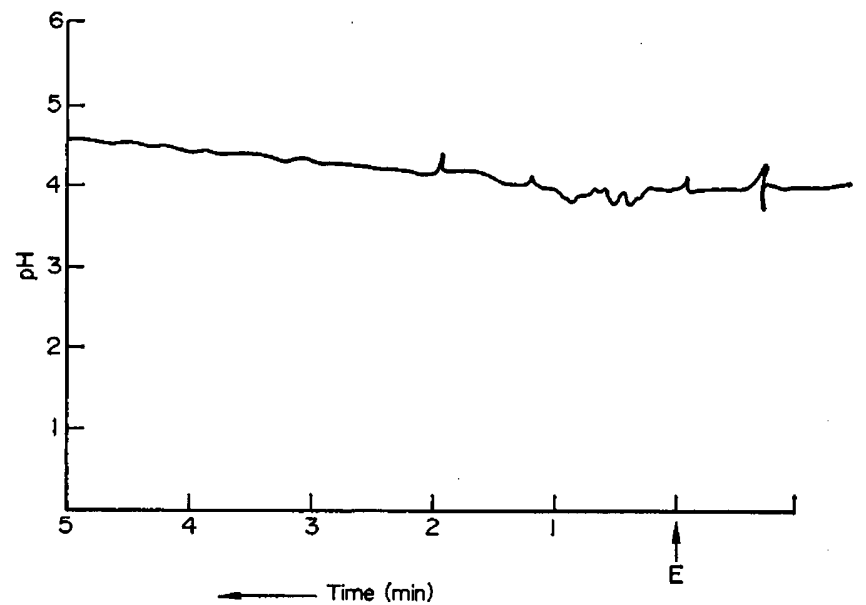

TEXT-FIG. 4. Effect of pH 3.6 buffer introduced into vagina before coitus in a fertile couple. Note very little change in vaginal $\mathrm{pH}$ during and after coitus. $\mathrm{E}=$ ejaculation.

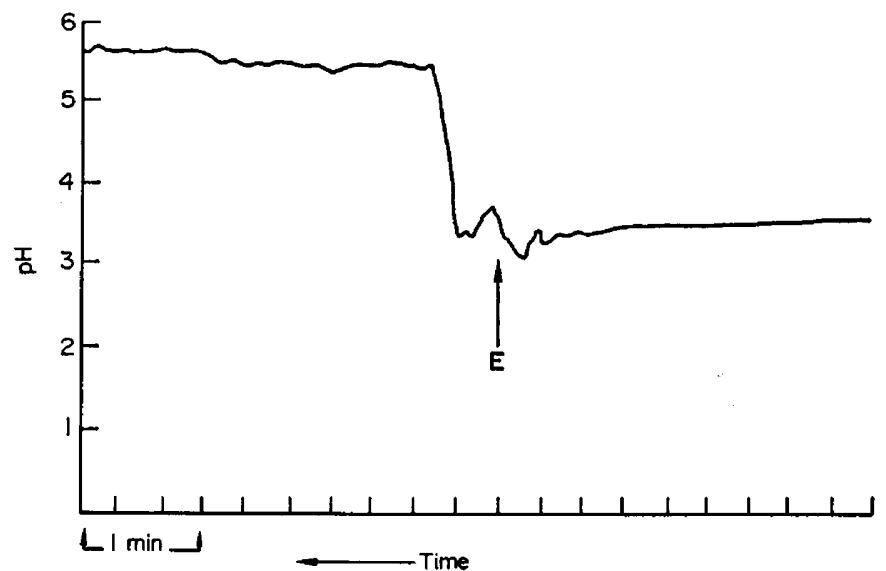

TexT-FIG. 5. Effect of poor seminal specimen (in subject of low fertility and with ejaculate of low volume and sperm count) on vaginal $\mathrm{pH}$ during and after human coitus. Note smaller and slower change in vaginal $\mathrm{pH} . \mathrm{E}=$ ejaculation. 
sperm motility, taken after 3,30 and $90 \mathrm{~min}$ respectively, showed no motile spermatozoa present.

\section{Low male fertility}

The effect of the arrival of semen in the vagina was a change of vaginal $\mathrm{pH}$ from 3.5 to 5.5 in $15 \mathrm{sec}$, with a rise to $\mathrm{pH} 5.8$ after $3 \mathrm{~min}$ (Text-fig. 5 ). The vaginal $\mathrm{pH}$ remained at $5 \cdot 8$ for the next hour.

\section{DISCUSSION}

The studies of Muschat (1926) indicated that the motility of human spermatozoa ceased at a $\mathrm{pH}$ of less than 6 or more than 10. Shedlovsky et al. (1942) conducted titrations of human seminal fluid with acids and alkalis. Their excellent data show that certain acids, such as acetic and monochloracetic, were most effective, inhibiting sperm motility in less than $30 \mathrm{sec}$ if the $\mathrm{pH}$ was less than $4 \cdot 7$. They also remarked on the superiority of the spermicidal properties of well buffered tartrate and lactate solutions over solutions of the corresponding acids alone.

Basic studies on the biological characteristics of the normal vagina (Oberst \& Plass, 1936; Rakoff, Feo \& Goldstein, 1944), the composition and physiology of semen (White \& Macleod, 1963; Raboch \& Skachova, 1965) and the biochemistry of semen (Mann, 1964) have added greatly to our knowledge of this area of reproductive physiology, whilst Lang (1955) and Masters \& Johnson (1966) have reviewed the particular topic of vaginal acidity. The latter authors provide a useful summary of experiments in vitro, but their own experiments in vivo on the effect of seminal fluid on vaginal $\mathrm{pH}$ deserve some criticism. It is hard to imagine how they managed to take the first postcoital $\mathrm{pH}$ test only 9 sec after ejaculation, when it is recalled that they were using glass electrodes for intermittent $\mathrm{pH}$ measurement. Furthermore, the term 'lethal factor' is frequently used without any elucidation of the nature of this factor.

Our own experiments have been hampered by the difficulty in obtaining experimental subjects for this sort of research. The rapid change of vaginal $\mathrm{pH}$ noted in the fertile couple indicates the powerful buffering capacity of normal seminal fluid, and our results resemble those of Masters \& Johnson (1966). Our findings suggest that the vagina is not normally the hostile environment hitherto imagined. The failure of the stimulus of sexual excitement and its concomitant vaginal lubrication to change the vaginal $\mathrm{pH}$ is also noteworthy, and we question the nature of the 'sweating' described by Masters \& Johnson (1961), since one would imagine this to be a transudate with a $\mathrm{pH}$ similar to that of plasma (around $\mathrm{pH} 7$ ).

Repeated ejaculation is known to lower seminal volume and, in our experiments, low volume was equated with poor buffering power. A coexistent low sperm count could render a seminal specimen vulnerable to vaginal acidity. This is corroborated to some extent, notwithstanding cervical factors, by the success of AIH in our hitherto infertile couple.

By altering the chemistry of the vaginal secretion with the introduction of $10 \mathrm{ml}$ buffer, $\mathrm{pH} 3 \cdot 6$, we were able to counteract the buffering power of normal 
seminal fluid to such an extent that there was little change in vaginal $\mathrm{pH}$ after ejaculation. The telemetering device was left in situ for $2 \mathrm{hr}$ but the maximal change was to $\mathrm{pH} 5 \cdot 4$. This suggests a possible field of investigation for a chemical contraceptive, since we have a scientific understanding of its mode of action. Such a buffer might affect the cervical mucus, which has a slightly alkaline $\mathrm{pH}$, and might adversely affect sperm transport (see Odeblad, 1962, 1971; Davajan, Nakamura \& Kharma, 1970). On the other hand, if some spermatozoa were sucked into the uterus during female orgasm (Fox \& Fox, 1967; Fox et al., 1970), they might escape the effects of the spermicide, and live spermatozoa could still be in the uterus in the presence of a negative postcoital test.

The use of a $\mathrm{pH} 7 \cdot 4$ buffer could be considered in certain cases of infertility.

\section{AGKNOWLEDGMENTS}

We are grateful to Mr C. N. Hudson, Reader in Obstetrics and Gynaecology, for his encouragement, and for reading the manuscript. We also thank $\operatorname{Dr} \mathrm{T}$. Chard, Mr R. Jacob and Mr R. Woodrough for helpful discussion. Finally, we thank Miss M. Hodges and Mr M. Pollard for designing and making the buffer solutions.

\section{REFERENGES}

Anderson, J. (1946) The buffer capacity and the specific gravity of bull semen. F. agric. Sci., Camb. 36, 258.

Baker, J. R., Ranson, R. M. \& Tynen, J. (1937) The spermicidal powers of chemical contraceptives. VII. Approved tests. F. Hyg., Camb. 37, 474.

Blackshaw, A. W. \& Emmens, C. W. (1951) The interaction of $\mathrm{pH}$, osmotic pressure and electrolyte concentration on the motility of ram, bull and human spermatozoa. J. Physiol., Lond. 114, 16.

Davajan, V., Nakamura, R. \& Kharma, K. (1970) Spermatozoan transport in cervical mucus. Obstetl gynec. Surv. 25, 1.

Diasio, R. B. \& Glass, R. H. (1971) Effects of $\mathrm{pH}$ on migration of $\mathrm{X}$ and $\mathrm{Y}$ sperm. Fert. Steril. 22, 303.

EAsLey, G. T., MAYer, D. T. \& Bogart, R. (1942) Influence of diluters, rate of cooling, and storage temperatures on survival of bull sperm. Am. F. vet. Res. 3, 358.

Fox, C. A. \& Fox, B. (1967) Uterine suction during orgasm. Br. med. F. i, 300.

Fox, C. A., WolfF, H. S. \& Baker, J. A. (1970) Measurement of intra-vaginal and intra-uterine pressures during human coitus by radio-telemetry. 7. Reprod. Fert. 22, 243.

LANG, W. R. (1955) Vaginal acidity and pH. A review. Obstetl gynec. Surv. 10, 546.

MANN, T. (1964) The biochemistry of semen and of the male reproductive tract, chapter IV. Methuen, London.

Masters, W. H. (1959) The sexual response cycle of the human female: vaginal lubrication. Ann. N.Y. Acad. Sci. 83, 301.

Masters, W. H. (1960) Influence of male ejaculate on vaginal acidity. In: Endocrine Dysfunction and Infertility, p. 76. Report of the 35th Ross Conference on Pediatric Research. Ed. S. J. Fomon. Ross Laboratories, Columbus, Ohio.

Masters, W. H. \& Johnson, V. E. (1961) The physiology of vaginal reproductive function. West. F. Surg. Obstet. Gynec. 69, 105.

Masters, W. H. \& Johnson, V. E. (1966) Human sexual response, p. 88. Churchill, London.

Muschat, M. (1926) The effect of variation of hydrogen-ion concentration on the motility of human spermatozoa. Surgery Gynec. Obstet. 42, 778.

Oberst, F. W. \& Plass, E. D. (1936) The hydrogen ion concentration of human vaginal discharge. Am. 7. Obstet. Gynec. 32, 22.

OdebLAD, E. (1962) Undulations of macromolecules in cervical mucus. Int. F. Fert. 7, 313.

Odeblad, E. (1971) Cervical factors. In: Control of Human Fertility, p. 89. Proceedings of the 15th Nobel Symposium. Eds. E. Diczfaluzy and U. Borell. Almquist \& Wiksell, Stockholm.

Raboch, J. \& Skachova, J. (1965) The pH of human ejaculate. Fert. Steril. 16, 252.

Rakofr, A. E., Feo, L. G. \& Goldstein, L. (1944) The biologic characteristics of the normal vagina. Am. J. Obstet. Gynec. 47, 467. 
Randall, A. \& Muschat, M. (1926) Hydrogen ion studies on various secretions of the uro-genital apparatus. F. Urol. 16, 515.

Shedlovsky, L., Bezcher, D. \& Levenstein, I. (1942) Titrations of human seminal fluid with acids and alkalis and their effects on the survival of sperm motility. Am. F. Physiol, 136, 535.

Smith, S. E. \& Asdelis, S. A. (1940) The buffering capacity of bull semen. Cornell Vet. 30, 499.

Tyler, E. T. (1959) The vagina and infertility. Ann. N.Y. Acad. Sci. 83, 294.

WATson, B. W. \& KAY, A. W. (1965) Radio-telemetering with special reference to the gastro-intestinal track. In: Biomechanics and Related Bio-Medical Engineering Topics. Ed. R. M. Kenedi. Pergamon Press, Oxford.

Whire, I. G. \& MACLEod, J. (1963) Composition and physiology of semen. In: Mechanisms Concerned with Conception. Ed. C. G. Hartman. Pergamon Press, New York. 